\title{
Agroclimatic Risk Zoning of Avocado (Persea americana) in the Hydrographic Basin of Paraná River III, Brazil
}

\author{
Nathan Felipe da Silva Caldana ${ }^{1, *}$, Pablo Ricardo Nitsche ${ }^{2}$, Alan Carlos Martelócio ${ }^{2}$, \\ Anderson Paulo Rudke ${ }^{3}{ }^{(0)}$, Geovanna Cristina Zaro ${ }^{4}$, Luiz Gustavo Batista Ferreira ${ }^{2}$, \\ Paulo Vicente Contador Zaccheo ${ }^{2}$, Sergio Luiz Colucci de Carvalho ${ }^{2}$ and Jorge Alberto Martins ${ }^{1}$ \\ 1 Federal University of Technology-Parana, Londrina-PR 86036-370, Brazil; jmartins@utfpr.edu.br \\ 2 Agronomic Institute of Parana, Agrometeorology and Plant Physiology Section, \\ Londrina-PR 86047-902, Brazil; pablonitsche@gmail.com (P.R.N.); amartelocio@agronomo.eng.br (A.C.M.); \\ luiz.gustavo@agronomo.eng.br (L.G.B.F.); paulozaccheo@gmail.com (P.V.C.Z.); \\ sergiofruticulturaiapar@gmail.com (S.L.C.d.C.) \\ 3 Department of Sanitary and Environmental Engineering, Federal University of Minas Gerais, Belo \\ Horizonte 31270-010, Brazil; rudke@alunos.utfpr.edu.br \\ 4 School of Environmental Science, University of Guelph, Guelph, ON N1G 2W1, Canada; \\ geoczaro@gmail.com \\ * Correspondence: nathancaldana@gmail.com
}

Received: 27 October 2019; Accepted: 10 December 2019; Published: 13 December 2019

check for updates

\begin{abstract}
Fruticulture is a prominent component of Brazilian agriculture. Studies have shown that climatic variability and its impact on the physiological development of plant species are fundamental for planning the agricultural calendar, resource conservation, and sustainable management of production. In this context, one of the first criterion for planting a crop is agroclimatic zoning, since it provides information on climate-related risks and aids decision-making and agricultural planning. The objective of this study was to carry out climatic risk zoning for avocado (Persea americana Mill.) in the basin of Paraná River III, Paraná State, Brazil. Meteorological data from 43 stations, from 1976 to 2018, were used. The climatic risk analysis was based on the requirements of the avocado for precipitation, water balance, average annual temperature, and frost tolerance. Statistical and geoprocessing techniques ensured full regional coverage of data and contributed to decision-making. The results identified favorable climatic conditions for all climatic variables in the western part of the river basin. Despite water deficits in some months, rainfall and water balance were not restrictive for avocado production in the region. Avocado tree cultivation is not recommended in the eastern part of the basin, where there is a considerable risk of frost.
\end{abstract}

Keywords: avocado; hydrographic basin of Paraná River III; climate aptitude; climate variability; agricultural planning

\section{Introduction}

Fruticulture is an activity that makes a key contribution to the national economic development of Brazil. According to the literature, fruticulture is an agricultural activity that is subject to meteorological and climatic risks [1-3]. Studies of meteorological elements on a global scale have allowed for improvements in our understanding of the relationship between the environment and cultivated plants, including fruit crop plants, both for zoning, planning, and preparation of agricultural calendars based on conservationist agriculture principles [1,4-7]. 
From this perspective, the avocado (Persea americana Mill.), a fruit tree typically grown in tropical climates, stands out for its importance for sustainable agriculture, climate change, and the expansion of its cultivation below the tropics. It belongs to the Lauraceae family and originates from the American continent. The avocado has the versatility to adapt to many agricultural production systems. This ability is mainly seen in agroforestry systems because they can recover, or even increase, soil fertility and provide aggregate stability [8]. Among other advantages, it has the ability to regulate the water cycle [9], increase carbon dioxide capture, and increase local biodiversity [10]. Avocadoes can be grown alongside other fruit species, optimizing land use, and can also be used for shading coffee [11-13].

The commercial fruiting of the grafted avocado tree starts from the third or fourth year of age, with an average yield of 12 to $30 \mathrm{~kg} /$ plant, varying by cultivar, climate, seedling quality, soil fertility, and cultural treatments, and the yield production may increase gradually as the plant develops [14,15]. The development of the production of this crop has been increased in recent years, motivated by its nutritional qualities and versatility, because the fruits are rich in vitamins A, C, E, and B-complex [15,16].

Paraná State, in the south of Brazil, has a low rate of avocado production compared to other fruits. In 2017, it recorded a production of 20 tons over an area of approximately 1000 hectares, of which 591 tons were recorded in the hydrographic basin of Paraná River III from an area of 25 hectares [17]. Several studies have been carried out globally to improve management techniques and increase avocado production and productivity [15,18-24]. As agroclimatic zoning is the first criterion to be considered when planning the development of a new crop, studies of this type are fundamental for the expansion of avocado production.

The purpose of this study was to perform climate risk agricultural zoning for the avocado in the hydrographic basin of Paraná River III, a drainage area on the left bank of the Itaipu Reservoir between River Iguaçu and River Piquiri.

\section{Materials and Methods}

\subsection{Climate Variability}

The hydrographic basin of Paraná River III is located in a Cfa climate, which means that it has a humid subtropical climate according to the Köppen climate classification. This is characterized by the absence of drought seasons and by summers with higher average temperatures. This climate is controlled by airmasses from tropical regions (the Atlantic Tropical Mass and the Continental Tropical Mass) and the Atlantic Polar Mass. In addition, the Continental Equatorial Mass can influence the Cfa climate zone during the summer season. Due to the temperature and humidity differences in these climatic masses, the area of the basin is a convergence zone for these climatic front systems, particularly in the winter season period [25].

For the purpose of this study, we selected the hydroclimatic requirements of the studied species and weather data of annual, seasonal, monthly, and daily time series with clipping from 1976 to 2018 . In order to analyze climate variability and produce the climate risk zoning, data from meteorological stations distributed around the basin were surveyed. The database comprises data from numerous weather stations, including six IAPAR-Instituto Agronomico do Paraná (Brazil) stations (data from 1976 to 2018), ten SIMEPAR-Sistema Meteorológico do Paraná (Brazil) stations (data from 2000 to 2018 were included to contribute to analyses, even though a short period of time), and 27 Águas Paraná (Brazil) stations (data from 1976 to 2018); see Figure 1. 


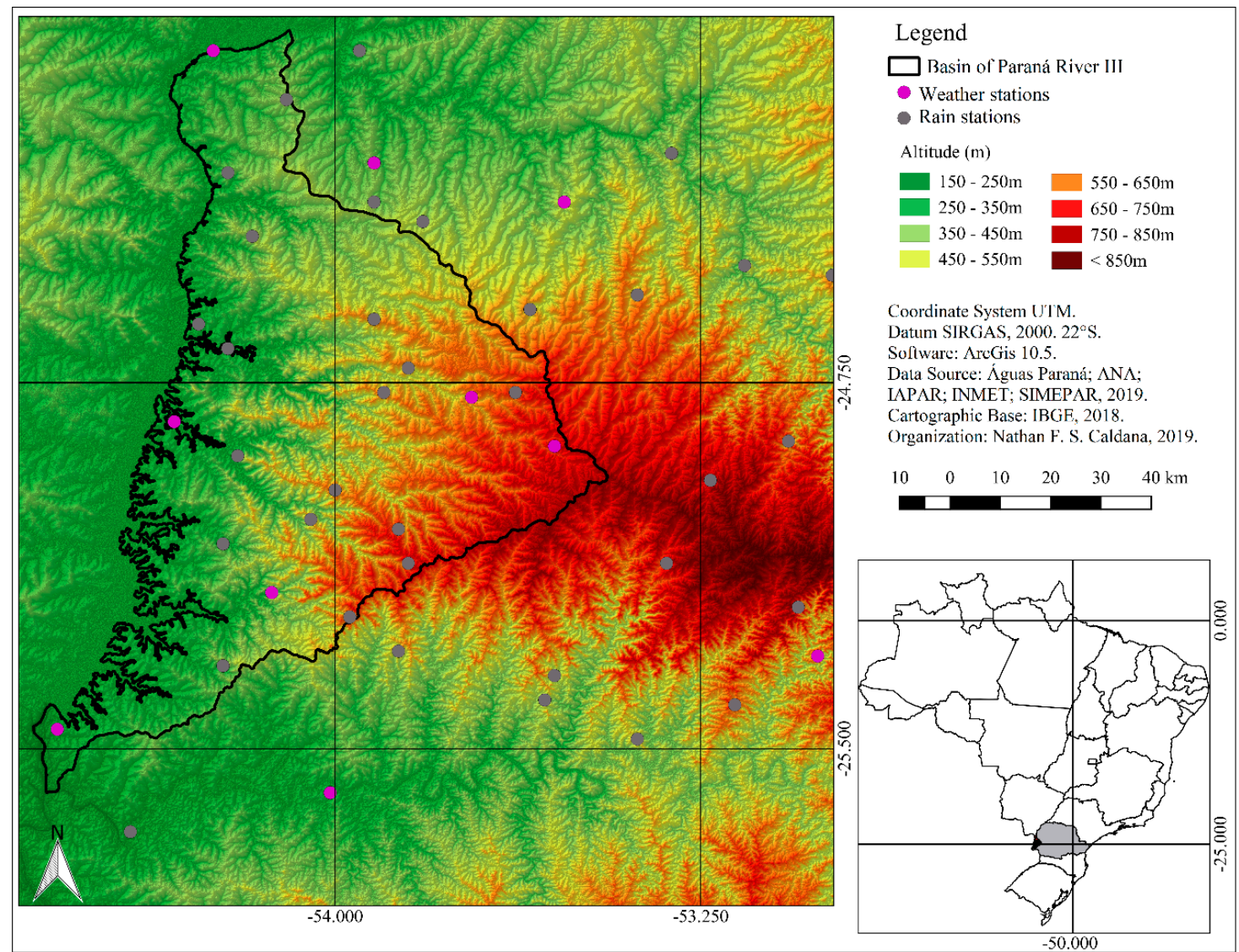

Figure 1. Hypsometry and locations of stations in the hydrographic basin of the Paraná River III.

For this study, we used data from stations that had long term data series (1976-2018). The spatialization of these data was performed by interpolation, which is an effective method for spatial visualization of climate data. This was done using isohyets and/or by spatially filling the values through adjusted regression statistics, using the inverse distance weighted spatial interpolation algorithm [26]. The maps were created using QGIS software.

Rainfall data (from the monthly totals of each year) and the monthly average temperature (from the monthly averages of the daily values of each year) were extracted. Then, potential evapotranspiration (PET) was calculated according to the Thornthwaite method. First, the standard potential evapotranspiration (PET, $\mathrm{mm} / \mathrm{month}$ ) was calculated using the empirical formula:

$$
\begin{gathered}
\text { For : } 0<\mathrm{Tn}<26.5^{\circ} \mathrm{C} \\
\text { PET }=16\left(10 \frac{\mathrm{Tn}}{\mathrm{I}}\right)^{\mathrm{a}} \\
\text { For }: \mathrm{Tn} \geq 26.5^{\circ} \mathrm{CTn}^{2} \\
\text { PET }=-41585,+3224, \mathrm{Tn}-43.0 \mathrm{Tn}^{2}
\end{gathered}
$$

where $\mathrm{Tn}$ is the average temperature of month $n\left(n=1\right.$ is January, $n=2$ is February, etc.) in ${ }^{\circ} \mathrm{C}$, and I is an index that expresses the heat level of the region.

The value of I depends on the annual temperature cycle, integrating the thermal effect of each month, and is calculated using the formula

$$
\mathrm{I}=12(0.2 \mathrm{Ta})^{1514}
$$


The exponent "a", being a function of I, is also a regional thermal index, and is calculated using the expression

$$
a=0.49239+1.7912 \times 10^{-2} I-7.71 \times 10^{-5} I^{2}+6.75 \times 10^{-7} I^{3} .
$$

The PET value represents the total monthly potential evapotranspiration that would occur under the thermal conditions of a standard 30 day month, and with a $12 \mathrm{~h}$ photoperiod $(\mathrm{N})$ each day. Therefore, PET should be corrected for $\mathrm{N}$ and the number of days in the period.

$$
\operatorname{COR}=\left(\frac{N}{12}\right)\left(\frac{N D P}{31}\right)
$$

\subsection{Agroclimatic Risk Zoning}

The risk factors selected for agricultural climate risk zoning are:

(a) Annual Water Deficiency (AWD): This was estimated using the method of Thornthwaite and Matter (1955), and obtained by calculating the normal climatological water balance for the meteorological stations. We used a value of $100 \mathrm{~mm}$ for the available water capacity in the soil, considering that the avocado root system explores the soil profile to a depth of more than $1 \mathrm{~m}$ [26]. The results obtained were interpolated using the ArcGIS 10.0 geographic information system to generate the annual water deficit maps. The following thresholds were considered for the risk of water deficiency: high risk—AWD > $100 \mathrm{~mm}$; low risk—AWD < $100 \mathrm{~mm}[20,27,28]$.

(b) Average Annual Temperature (Ta): Meteorological data from historical series of average temperatures observed inside meteorological shelters were used to estimate the average annual temperature. Using the Ta value, regression was applied as a function of latitude, longitude, and altitude for the whole basin. The risk classes defined for Ta were as follows: high risk-below $19^{\circ} \mathrm{C}$; medium risk-between 19 and $21^{\circ} \mathrm{C}$; low risk—greater than $21^{\circ} \mathrm{C}[26,29,30]$.

(c) Frost Risk: We used meteorological data from the thirteen-season historical series, taking into account occurrences of temperatures of $1{ }^{\circ} \mathrm{C}$ or below as observed within the meteorological shelters, to calculate the risk of frost. The probabilities of annual frost occurrence were calculated and correlated with altitude and latitude, obtaining a regression equation for the risk of frost. Using adjusted regressions, values greater than $40 \%$ were considered to be high risk $[26,28,29]$.

For the creation of thematic maps and the final zoning map, ArcGIS software was used. Firstly, the numerical values from the meteorological stations were transformed into points, according to their geographical coordinates. We then used the edaphoclimatic requirements of the avocado species to produce data spatialization, which was used for the delimitation of the representative bands of the avocado climate requirements. Thus, the station values were replaced by "1. Apt" or "2. Restricted", according to the physiological requirements for each meteorological variable analyzed.

The next step was to combine the matrix images. Each pixel was assigned with the values " 1 " or " 2 ", as already described. If the combination for a point was filled only with values " 1 ", the region was classified as fit. If it had a value of " 2 " it was restricted by a given variable. If two or more " 2 " values were assigned, the location was classified as unfit.

Then, standardization of the pixels using classifications was performed by dissolving the vector classes. In this way, the agroclimatic zoning classes were grouped, thus defining regions of suitability for the studied species. The final map showing the agroclimatic zoning of each crop will provide an estimate of the representative area of each risk class, ensuring its suitability for the site.

\section{Results and Discussion}

The hydrographic basin of Paraná River III has a significant annual rainfall average (Figure 2). In the far north (Guaíra region), the annual rainfall average was $1550 \mathrm{~mm}$, while the highest rainfall averages values $(2125 \mathrm{~mm}$ ) were observed in the south of the basin (Cascavel region). 


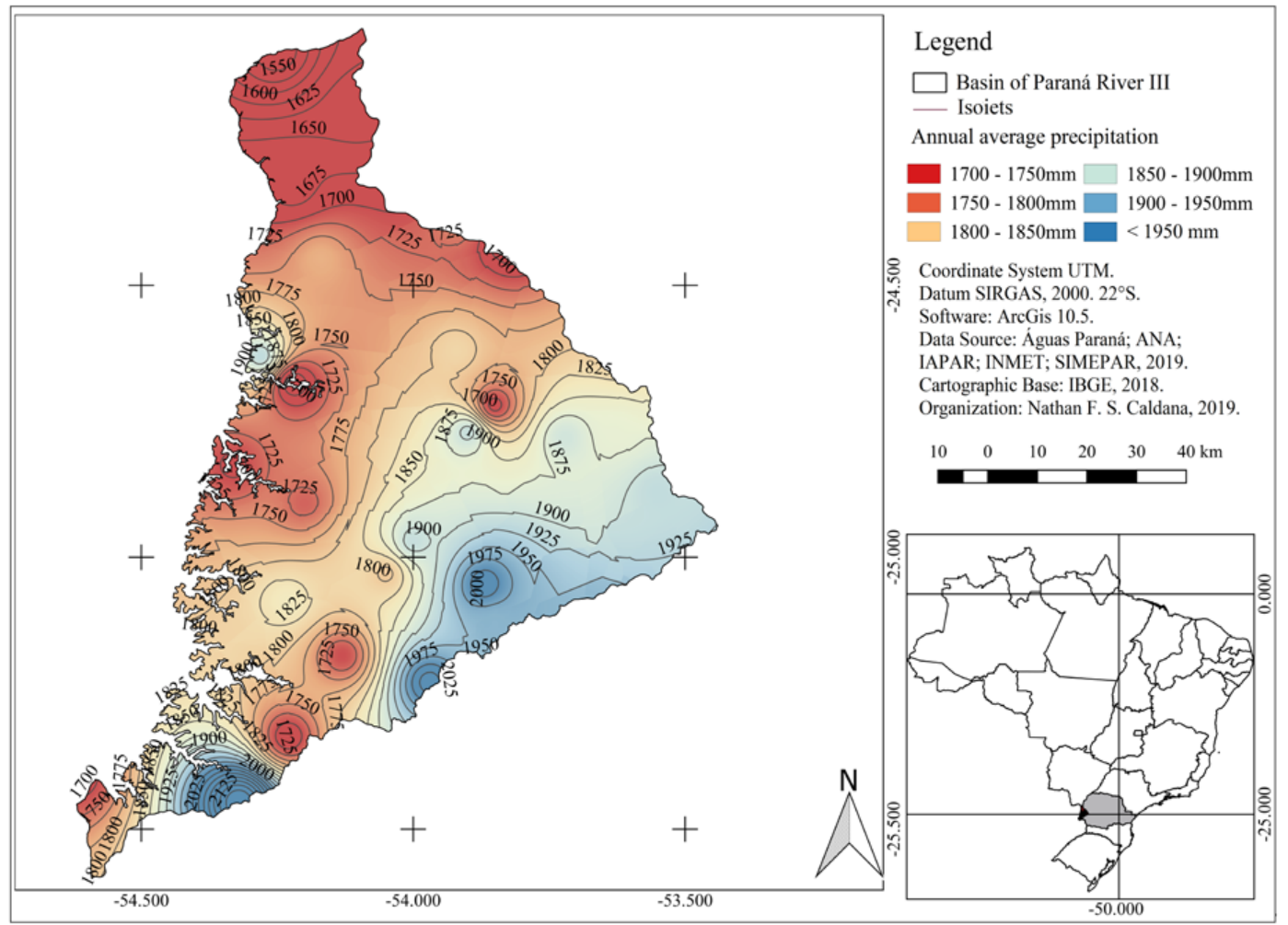

Figure 2. Annual rainfall average in the hydrographic basin of Paraná River III.

The average annual rainfall is sufficient for avocado cultivation across the entire area. The distribution and frequency of rainfall precipitation during the year are very important, particularly in the initial planting and development phase, as well as during the reproduction phase.

Although other regions of Paraná state experience the wettest month in January [27,31-33], the hydrographic basin of Paraná River III experiences the highest rainfall and the highest monthly median during October (Figure 3).

The municipality of Matelândia showed great rainfall variations in May, varying from $557 \mathrm{~mm}$ in 1992 to $2.5 \mathrm{~mm}$ in 2006. The only month without any rain in this season that has been recorded was August 1999. Seven outliers and one extreme were identified, that were concentrated mainly during the winter and spring months.

The municipality of Santa Lucia was identified as having the highest monthly rainfall, with $608 \mathrm{~mm}$ observed in June 2014. There were five outliers and two extremes in this location. Comparatively, there was a difference in the distribution of rainfall between municipalities of Matelândia and Santa Lucia, with December being wetter than November in the latter, and February wetter than May (see Figure 3).

The municipality of Terra Roxa exhibited the lowest monthly variation between Q1 (Quartile 1) and Q3, especially in July, with a variation of $43 \mathrm{~mm}$. By contrast, this municipality had the highest concentration of outliers (13) and extremes (5). Toledo exhibited the largest variation between quartiles, in May, with a difference of 202 and $566 \mathrm{~mm}$ between the maximum and minimum values. 


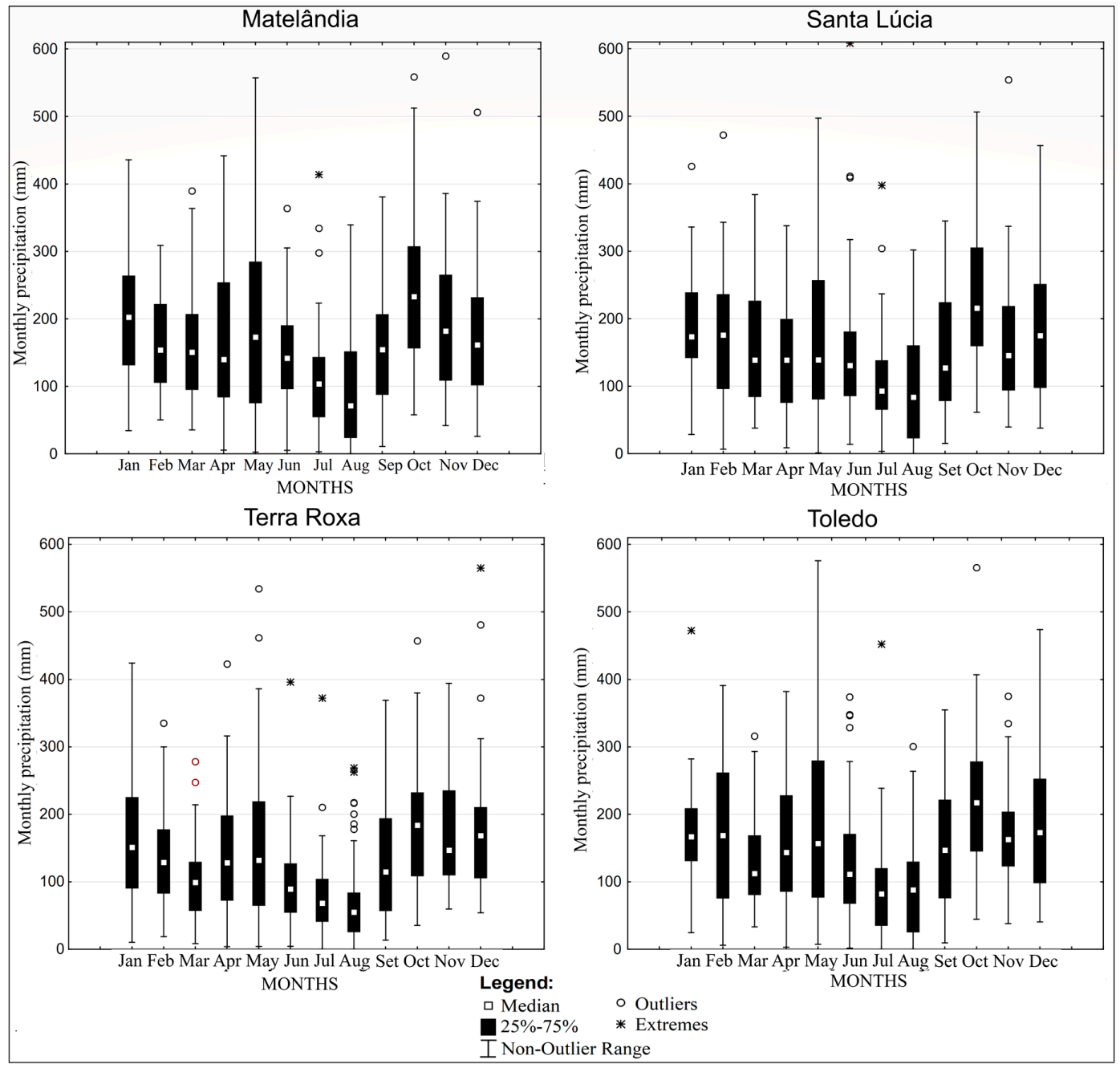

Figure 3. Annual rainfall variability in the hydrographic basin of Paraná River III.

The results showed a large monthly variation of precipitation in the region. This demonstrates the importance of climate zoning and can be used to determine the best planting times and appropriate management practices. The month of October had the best conditions for planting the seedlings, since it is the wettest month. From the box plot analysis, it was observed that July had the lowest recorded rainfall $(50 \mathrm{~mm})$, so the risk of planting in July is different from that of planting in the autumn and winter months, due to frequent occurrence of months without rain in the region.

It was determined that Cascavel, São Miguel do Iguaçu, and Toledo did not experience water deficiencies in any month (Figure 4) by water balance, while the municipality of Assis Chateabreand had only $1.2 \mathrm{~mm}$ of rainfall in March. Foz do Iguaçu and Guaíra experienced water deficiency in March, albeit with higher rainfall values (22 and $37 \mathrm{~mm}$, respectively). The water deficiency in Guaíra continued until May.

As the risk assessed was a cumulative annual of $100 \mathrm{~mm}$, no season presented risks for avocado cultivation. In Guaíra, which was observed to have greater deficiency, the accumulated rainfall was $56 \mathrm{~mm}$. Because avocado trees typically have deep roots, the plants can extract water from deeper soil layers or horizons [27]. The water balance was less favorable from January to April, due to high temperatures and increased evapotranspiration. The water annual deficiencies in these months would not prevent the establishment of the crop in the region, but the planting period should be adjusted to avoid drought periods. 


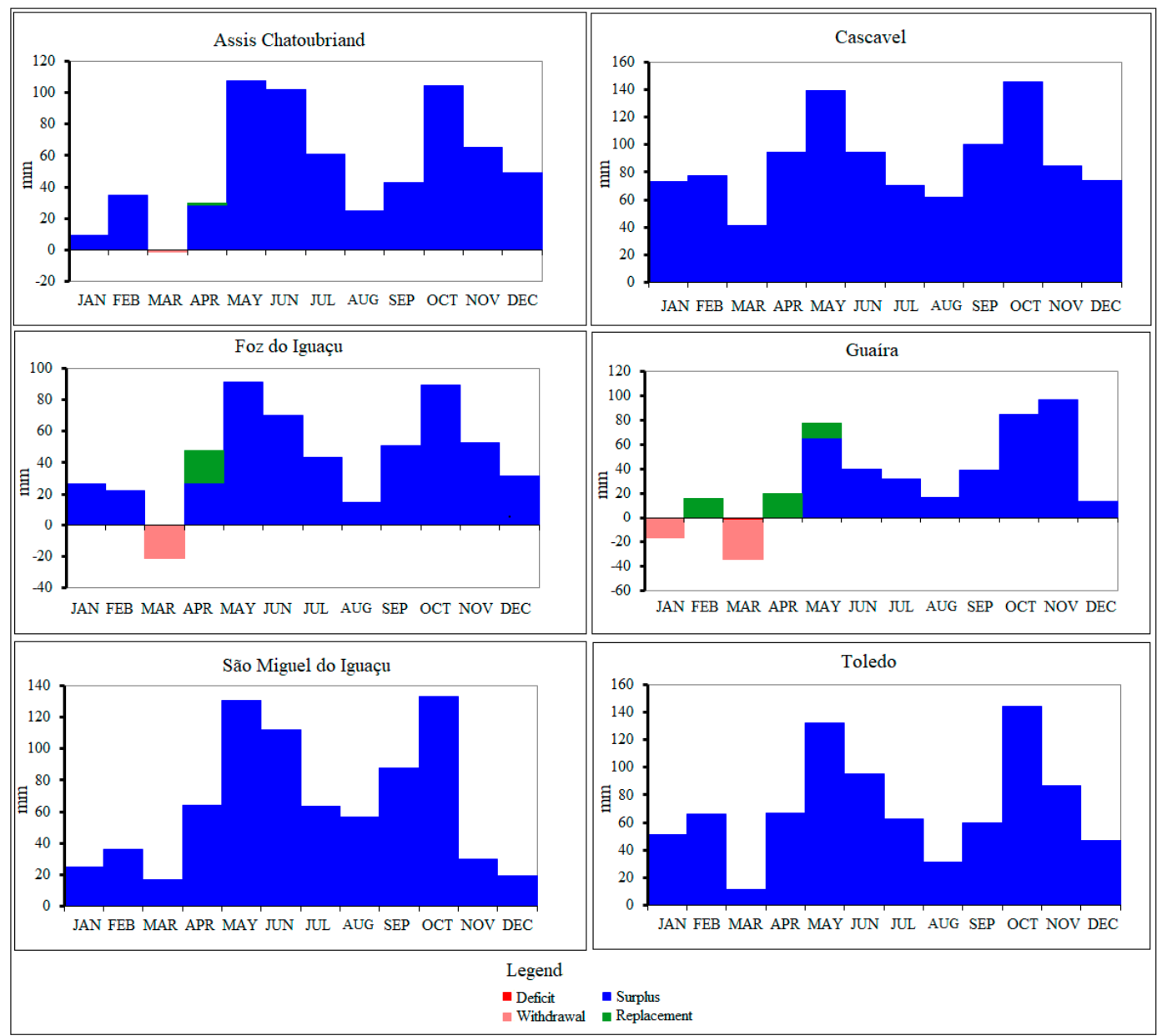

Figure 4. Water balance for avocado crop in the hydrographic basin of Paraná River III.

Avocado trees require a significant quantity of water. Therefore, it is recommended that they be cultivated in regions that have an annual average rainfall of around $1500 \mathrm{~m}$. In areas where the distribution of rainfall is irregular or insufficient, the of use irrigation at the beginning of planting is recommended to meet the needs of the plants and to ensure higher quality fruit are produced [27].

As can be seen, rainfall in the region is sufficient for the full development of avocado plants. Prolonged periods of drought can cause loss of flowers, reducing fruit production. Excessive rainfall during the flowering period may impair pollinator action and pollen quality, affecting fruiting [27].

The average annual temperature (Figure 5) was observed to show a similar pattern to the surface topography of the region. This justifies the proposed planting distribution, since the higher altitude areas near Cascavel experienced the lowest temperatures and the lower altitude areas experienced the highest average temperatures.

As been previously observed, the average annual temperature limit value for avocado production is $21^{\circ} \mathrm{C}$. The high-altitude areas of the Cascavel region had temperature values around $21^{\circ} \mathrm{C}$. The edges of the valleys in the central portion had average temperature values of $21.5^{\circ} \mathrm{C}$. The southern, western, and northern areas, which are closest to the Paraná River channel, had suitable temperatures with average values above $22{ }^{\circ} \mathrm{C}$. The highest average temperatures were observed in the Guaíra region, in the extreme north of the basin, which reached temperatures over $23^{\circ} \mathrm{C}$. The risk of annual frost in the region was similar to the average temperatures, with higher risk in the eastern area and in some valley bottoms in the most central area of the basin. 


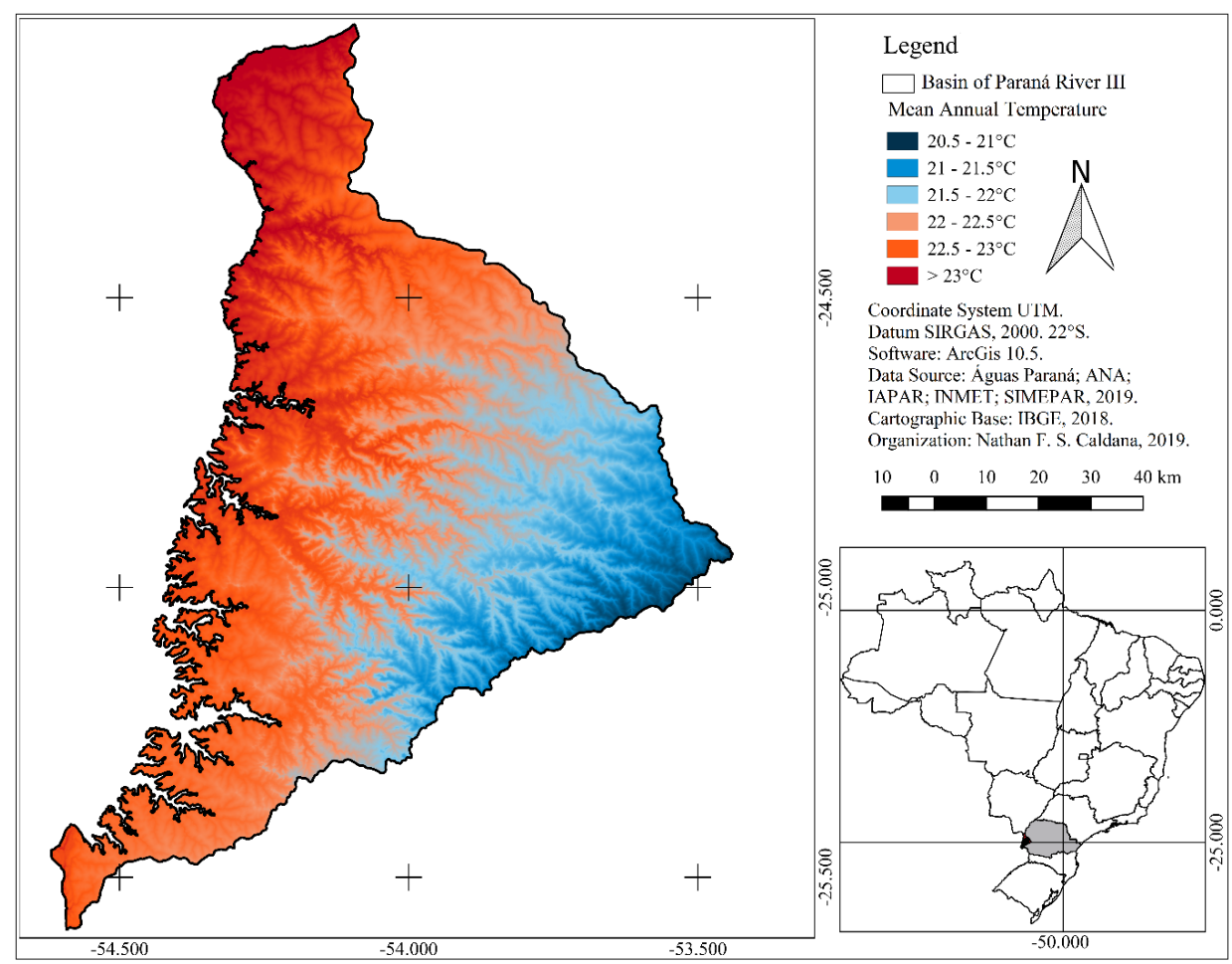

Figure 5. Annual average temperature in the hydrographic basin of Paraná River III.

The only unfit region was the far east, near Cascavel and Santa Tereza do Oeste, due to a high frost risk (above 25\%; Figure 6). It is noteworthy that the studied species is more sensitive to frost in its early years of development. In its adult phase, only extreme cold can damage the fruit and this does not lead to senescence [27].

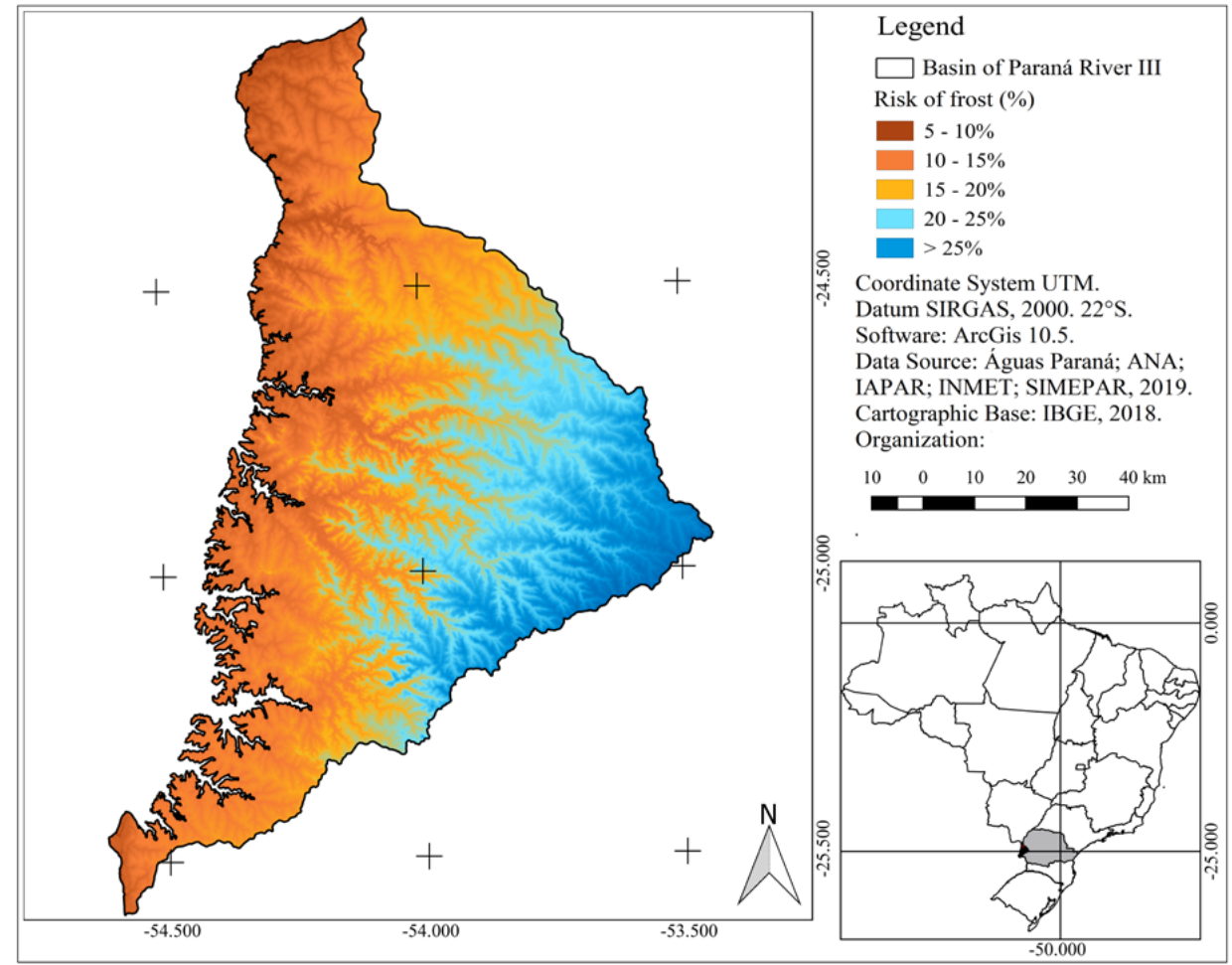

Figure 6. Frost risk in the hydrographic basin of Paraná River III. 
Figure 7 presents the final climate risk agricultural zoning for growing avocadoes. From this figure, it can be determined that the lower altitude areas in the north, west, and south regions have favorable conditions for avocado production for all analyzed variables.

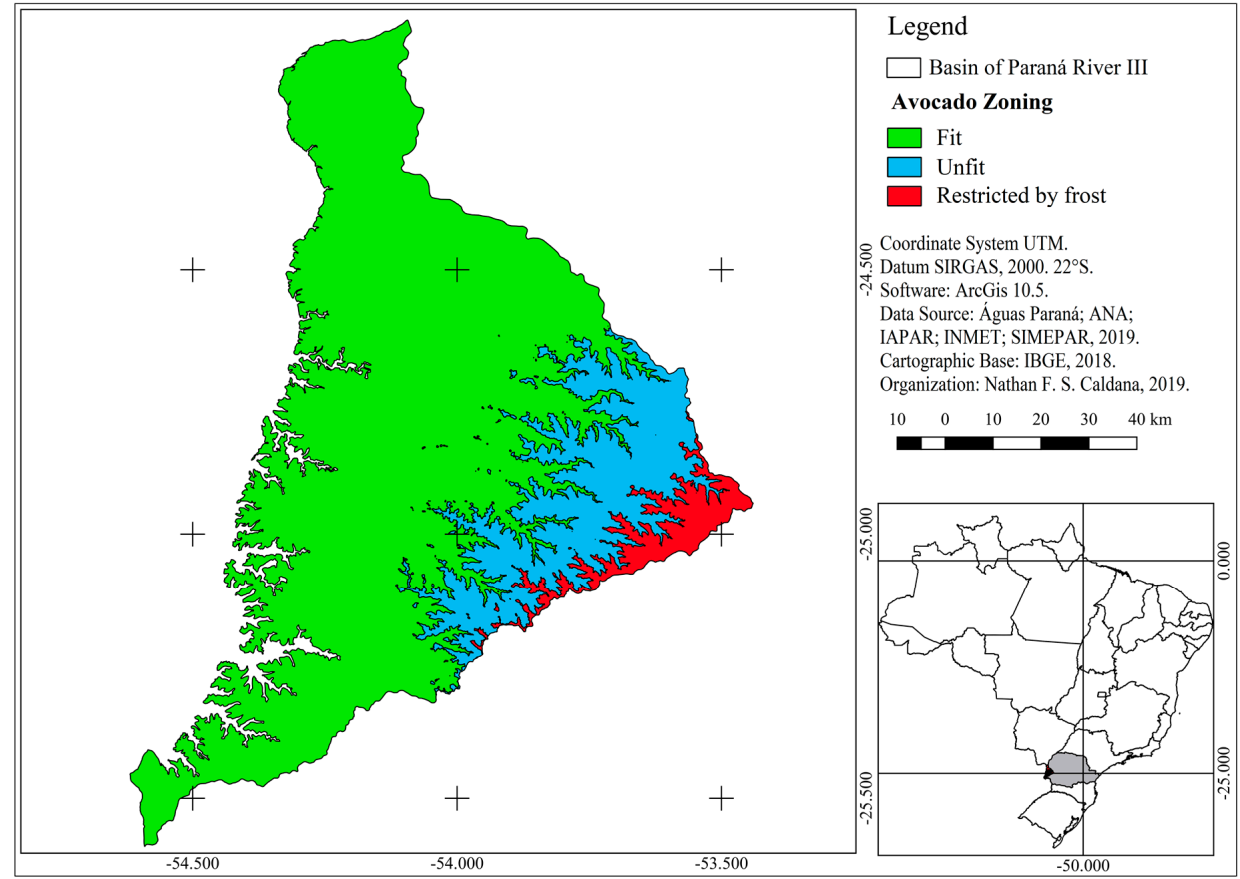

Figure 7. Agroclimatic risk zoning of avocado (Persea americana) in the hydrographic basin of Paraná River III.

A marginal region for production was identified in the central part, from the north to the south of the basin. This region faced restrictions solely due to frost, since all other factors showed aptitude for growing avocadoes. The risk of frost damage, as mentioned previously, is higher for newly planted orchards and, hence, frost protection methods may be required at this stage of development. Thus, producers should avoid the valley bottoms and base or tops of slopes, but should instead give preference to cultivation in areas that are not very steep to facilitate the movement of cold air. In particular, the hilltop and half slope should be used, especially in the north-facing sites. This is because, as has been already discussed, the cold front has preferential displacement in the south/southwest direction and in the northeast direction.

It should be noted that zoning does not eliminate the risks, but only presents more favorable conditions for the development of avocado orchards. As agriculture is a risky activity, all activities are susceptible to extreme events, which may or may not cause harm. Zoning provides greater security in decision-making, agricultural planning, and climate change scenarios, especially in the hydrographic basin of Paraná State III.

\section{Conclusions}

The hydrographic basin of Paraná River III contains areas of low climate risk for growing avocadoes, and only a small portion in the eastern part of the region was observed to have risk factors, which were mainly linked to frost. The region under study has sufficient rainfall for avocado cultivation. In marginal regions, care should be taken with orchard site selection, and it is important to avoid areas that are prone to frost. The use of management techniques and sustainable agriculture to mitigate climatic risks are also important.

It is recommended to plant new avocado orchards during the first week of October because of the water requirements of this species. Because of the long development time required for avocadoes 
to gain frost tolerance, protection practices should be implemented, especially for the first years of a newly planted orchard. In its adult phase, only extreme cold can damage the fruit, and this does not cause senescence. The eastern part of the region, which has higher altitudes and higher frost risk, is not suited for the cultivation of avocadoes.

Author Contributions: Conceptualization, N.F.d.S.C., A.C.M. and L.G.B.F.; Methodology, N.F.d.S.C.; A.P.R. and G.C.Z.; software, N.F.d.S.C. and P.R.N.; formal analysis, N.F.d.S.C. and P.R.N.; investigation, N.F.d.S.C. and P.R.N.; data curation, N.F.d.S.C., A.P.R. and A.C.M.; writing-original draft preparation, N.F.d.S.C. and L.G.B.F.; writing-review and editing, N.F.d.S.C., P.V.C.Z., S.L.C.d.C. and J.A.M.; visualization, N.F.d.S.C. and P.R.N.; supervision, N.F.d.S.C., P.V.C.Z., S.L.C.d.C. and J.A.M.

Funding: This research was funded by Itaipu Binacional and FAPEAGRO (Fundação Apoio a Pesquisa Desenvolvimento do Agronegócio) through the Projeto Ibitiba and process 4500040010.

Acknowledgments: The authors thank the Itaipu Binacional and the FAPEAGRO (Fundação Apoio a Pesquisa Desenvolvimento do Agronegócio) for granting a scholarship to the first author.

Conflicts of Interest: The authors declare no conflict of interest.

\section{References}

1. Cambui, E.C.B.; de Vasconcelos, R.N.; Mariano-Neto, E.; Viana, B.F.; Cardoso, M.Z. Positive forestry: The effect of rubber tree plantations on fruit feeding butterfly assemblages in the Brazilian Atlantic forest. For. Ecol. Manag. 2017, 397, 150-156. [CrossRef]

2. Oliveira, A.; Amaro, A.L.; Pintado, M. Impact of food matrix components on nutritional and functional properties of fruit-based products. Curr. Opin. Food Sci. 2018, 22, 153-159. [CrossRef]

3. Agovino, M.; Casaccia, M.; Ciommi, M.; Ferrara, M.; Marchesano, K. Agriculture, climate change and sustainability: The case of EU-28. Ecol. Indic. 2019, 105, 525-543. [CrossRef]

4. Ezenne, G.I.; Jupp, L.; Mantel, S.K.; Tanner, J.L. Current and potential capabilities of UAS for crop water productivity in precision agriculture. Agric. Water Manag. 2019, 218, 158-164. [CrossRef]

5. Hassani, Y.; Shahdany, S.M.H.; Maestre, J.M.; Zahraie, B.; Ghorbani, M.; Hennebery, S.R.; Kulshreshtha, S.N. An economic-operational framework for optimum agricultural water distribution in irrigation districts without water marketing. Agric. Water Manag. 2019, 221, 348-361. [CrossRef]

6. Novoa, V.; Ahumada-Rudolph, R.; Rojas, O.; Sáez, K.; de la Barrera, F.; Arumí, J.L. Understanding agricultural water footprint variability to improve water management in Chile. Sci. Total Environ. 2019, 670, 188-199. [CrossRef]

7. Ogilvie, A.; Riaux, J.; Massuel, S.; Mulligan, M.; Belaud, G.; Le Goulven, P.; Calvez, R. Socio-hydrological drivers of agricultural water use in small reservoirs. Agric. Water Manag. 2019, 218, 17-29. [CrossRef]

8. Mendonça, E.S.; Stott, D.E. Characteristics and decomposition rates of pruning esidues from a shaded coffee system in Southeastern Brazil. Agrofor. Syst. 2003, 57, 117-125. [CrossRef]

9. Giraldo, J.F.; Jaramillo, A. Ciclo hidrológico y transporte de nutrimentos en cafetales bajo diferentes densidades de sombrío de guamo. Cenicafé (Colombia) 2004, 55, 52-68.

10. Perfecto, I.; Vandermeer, J.; Mas, A.; Pinto, L.S. Biodiversity, yield, and shade coffee certification. Ecol. Econ. 2005, 54, 435-446. [CrossRef]

11. Jaramillo-Botero, C.; Santos, R.H.S.; Fardim, M.P.; Pontes, T.M.; Sarmiento, F. Produção de serapilheira e aporte de nutrientes de espécies arbóreas nativas em um sistema agroflorestal na Zona da Mata de Minas Gerais. Revista Árvore 2008, 32, 869-877. [CrossRef]

12. Silva, J.; Jucksch, I.; Maia, C.I.; Feres, A.; Castro Tavares, R. Fauna do solo em sistemas de manejo com café. J. Biotechnol. Biodivers. 2012, 3, 59-71. [CrossRef]

13. Meylan, L.; Merot, A.; Gary, C.; Rapidel, B. Combining a typology and a conceptual model of cropping system to explore the diversity of relationships between ecosystem services: The case of erosion control in coffee-based agroforestry systems in Costa Rica. Agric. Syst. 2013, 118, 52-64. [CrossRef]

14. Castro, P.R.; Kluge, R.A. Ecofisiologia de Fruteiras: Abacateiro, Aceroleira, Macieira, Pereira e Videira; Editora Agronomica Ceres Ltda: Piracicaba, Brazil, 2003.

15. Araújo, R.G.; Rodriguez-Jasso, R.M.; Ruiz, H.A.; Pintado, M.M.E.; Aguilar, C.N. Avocado by-products: Nutritional and functional properties. Trends Food Sci. Technol. 2018, 80, 51-60. [CrossRef] 
16. Francisco, V.L.F.D.S.; Baptistella, C.S.L. Cultura do abacate no Estado de Sâo Paulo. Informações Econômicas 2005, 35, 27-41. Available online: http://www.iea.sp.gov.br/ftpiea/ie/2005/tec3-0505.pdf (accessed on 15 May 2019).

17. Ipardes, Instituto Paranaense de Desenvolvimento Econômico e Social. Produção de Abacate; 2019. Available online: http://www.ipardes.gov.br/imp/index.php (accessed on 22 May 2019).

18. Bonvehi, J.S.; Coll, F.V.; Bermejo, J.O. Characterization of avocado honey (Persea americana Mill.) produced in Southern Spain. Food Chem. 2019, 287, 214-221. [CrossRef]

19. Freeman, S.; Miller, G.; Protasov, A.; Maymon, M.; Elazar, M.; David-Schwartz, R.; Zhou, J.; Mendel, Z. Aposymbiotic interactions of three ambrosia beetle fungi with avocado trees. Fungal Ecol. 2019, 39, 117-130. [CrossRef]

20. Moreno-Ortega, G.; Pliego, C.; Sarmiento, D.; Barceló, A.; Martínez-Ferri, E. Yield and fruit quality of avocado trees under different regimes of water supply in the subtropical coast of Spain. Agric. Water Manag. 2019, 221, 192-201. [CrossRef]

21. Rodríguez, I.; Cámara-Martos, F.; Flores, J.M.; Serrano, S. Spanish avocado (Persea americana Mill.) honey: Authentication based on its composition criteria, mineral content and sensory attributes. LWT 2019, 111, 561-572. [CrossRef]

22. Santana, I.; Castelo-Branco, V.N.; Guimarães, B.M.; de Oliveira Silva, L.; Peixoto, V.O.D.S.; Cabral, L.M.C.; Freitas, S.P.; Torres, A.G. Hass avocado (Persea americana Mill.) oil enriched in phenolic compounds and tocopherols by expeller-pressing the unpeeled microwave dried fruit. Food Chem. 2019, 286, 354-361. [CrossRef]

23. Shezi, S.; Magwaza, L.S.; Mashilo, J.; Tesfay, S.Z.; Mditshwa, A. Photosynthetic efficiency and relationship to mesocarp dry matter content of 'Carmen'avocado (Persea americana Mill.) fruit in a cool subtropical climate. Sci. Hortic. 2019, 253, 209-216. [CrossRef]

24. Tan, C.X. Virgin avocado oil: An emerging source of functional fruit oil. J. Funct. Foods 2019, 54, 381-392. [CrossRef]

25. Nitsche, P.R.; Caramori, P.H.; Ricce, W.S.; Pinto, L.F.D. Atlas Climático do Estado do Paraná. Instituto Agronômico do Paraná 2019. Available online: http://www.iapar.br/modules/conteudo/conteudo.php? conteudo=677 (accessed on 2 May 2019).

26. Lem, S.; Onghena, P.; Verschaffel, L.; Van Dooren, W. The heuristic interpretation of box plots. Learn. Instr. 2013, 26, 22-35. [CrossRef]

27. Zaro, G.C.; Ricce, W.D.S.; Caramori, P.H.; Carvalho, S.L.C.; Vicentini, M.E. Zoneamento agroclimático para a cultura do abacateiro no Estado do Paraná. Revista Brasileira de Fruticultura 2014, 36, 363-372. [CrossRef]

28. Zaro, G.C.; Caramori, P.H.; Kitzberger, C.S.G.; Sales, F.A.; de Carvalho, S.L.C.; Prete, C.E.C. Phenological cycle and physicochemical characteristics of avocado cultivars in subtropical conditions. Aims Energy 2017, 5, 517-528. [CrossRef]

29. Cunha, G.A.P.D. Applied aspects of pineapple flowering. Bragantia 2005, 64, 499-516. [CrossRef]

30. Ricce, W.S.; de Carvalho, S.L.C.; Caramori, P.H.; Auler, P.A.M.; Roberto, S.R. Zoneamento agroclimático da cultura do abacaxizeiro no Estado do Paraná. Semina Ciências Agrárias 2014, 35, 2337-2345. [CrossRef]

31. Caldana, N.F.S.; Junior, G.M.Y.; de Moura, D.A.V.; da Costa, A.B.F.; Caramori, P.H. Ocorrências de Alagamentos, Enxurradas e Inundações e a Variabilidade Pluviométrica na Bacia Hidrográfica do Rio Iguaçu. Revista Brasileira de Climatologia 2018, 23, 343-355. [CrossRef]

32. Caldana, N.F.S.; Rudke, A.P.; da Silva, I.; Nitsche, P.R.; Caramori, P.H. Gênese, Impacto e a Variabilidade das Precipitações de Granizo na Mesorregião Centro-Sul Paranaense, Brasil. Caderno de Geografia 2019, 29, 61-80. [CrossRef]

33. Caldana, N.F.S.; Martelócio, A.C. Gênese, frequência e intensidade das precipitações de granizo nas Mesorregiões Centro Oriental e Sudeste Paranaense, Brasil. GeoTextos 2019, 15, 205-229. [CrossRef]

(C) 2019 by the authors. Licensee MDPI, Basel, Switzerland. This article is an open access article distributed under the terms and conditions of the Creative Commons Attribution (CC BY) license (http://creativecommons.org/licenses/by/4.0/). 